\title{
ACMT Position Statement: The Iom Report on Thimerosal and Autism
}

\author{
Tom L. Kurt
}

PREPARED BY THE ACMT PRACTICE COMMITTEE. REPRINTED FROM WWW.ACMT.NET

The American College of Medical Toxicology (ACMT) is a professional society composed of physician toxicologists who focus on the diagnosis and management of acute and chronic adverse health effects due to medications, chemical, occupational and environmental toxicants and biological hazards. The ACMT commends the efforts of the IOM report of Immunization Safety Review: Vaccines and Autism [1]. The ACMT notes that the Immunization Safety Review Committee, while comprised of many competent academicians, had none with the special skill set of a medical toxicologist, a critical criterion when the adverse effects of an organomercurial are being considered. The IOM is encouraged to include medical toxicologists on committees that focus on potential toxicologic exposures. Indeed, in the past, a medical toxicologist has stepped forward on this issue [2].

The IOM concludes that the body of epidemiological evidence indicates that there is no causal relationship between thimerosal containing vaccines and autism. The ACMT provides the following background and comments. Thimerosal is a mercury-containing organic compound (sodium ethylmercuric thiosalicylate, also known as Merthiolate, Mercurothiolate) which contains approximately $50 \%$ mercury by weight [3]. The United States Code of Federal Regulations (CFR) requires the addition of a preservative to multi-dose vials of vaccines. Since the 1930's, thimerosal has been widely used as a preservative in a number of biological and drug products, to help prevent contamination from microbes. When the Food, Drug and Cosmetic Act was passed in 1938, thimerosal was placed on the GRAS (generally recognized as safe) list. Thimerosal in concentrations of $0.001 \%$ (1 part in 100,000 ) to $0.01 \%$ ( 1 part in 10,000 ) has been shown to be effective in clearing a broad spectrum of pathogens. Placed in perspective, a vaccine containing $0.01 \%$ thimerosal as a preservative contains 50 micrograms of thimerosal per $0.5 \mathrm{~mL}$ dose or approximately 25 micrograms of mercury per $0.5 \mathrm{~mL}$ dose, in the form of ethyl mercury. As the number of vaccinations given to infants has increased, so has the cumulative exposure to Thimerosal as the organomercurial preservative [4].

In 1999, with a recognized increase in the prevalence of autism spectrum syndromes, attention was called to thimerosal as a potential risk factor, especially in combination with measles, mumps and rubella (MMR) vaccination [4-9]. At that time the Public Health Service (including the Food and Drug Administration [FDA], National Institutes of Health, and the Centers for Disease Control and Prevention [CDC]), and the American Academy of Pediatrics (AAP) called for the withdrawal of thimerosal from further use in vaccines targeted for children. However, thimerosal in existing vaccine inventory was allowed to be used.

Much of this concern was based on methylmercury-related neurotoxicity, the timing of vaccination during the first year of life when the blood-brain barrier is more permeable to heavy metals, and a model that equated intermittent exposure to ethylmercury to cumulative dosing of methylmercury. Recent research has confirmed that the ethylmercury component found in Thimerosal is less hazardous than methylmercury. These are different compounds and should not be considered as equivalent neurotoxins. Experimental conditions can be created that result in neurological cell dysfunction $[10,11]$. However, current literature supports the contention that childhood vaccinations do not deliver a sufficient dose to produce these neurological injuries.

Several large epidemiological studies have been completed in an attempt to clarify the issue of childhood immunizations and the risk of neurodevelopmental disorders. The CDC reviewed computer-based vaccination records and ICD-9 codes of autistic spectrum disorders for over 124,000 infants at two health maintenance organizations (HMOs) in California [12]. In 2003, a published comparison of imputed thimerosal dose in Sweden, Denmark and the United States found no correlation with the rise in prevalence of autism spectrum disorders occurring in all three countries [13]. The Institute of Medicine (IOM) of the National Academy of Sciences assembled an Immunization Safety Review Committee that held hearings and provided a series of reports, culminating in their 2004 Immunization Safety Review: Vaccines and Autism [1].

Although a number of potential concerns have been raised regarding the adequacy of the IOM review (7 months, rather than one year catchment period, and procedural issues such as 
cutoff age and ICD-9 diagnostic listings), the ACMT believes that the IOM's conclusions are justified. In fact, in conjunction with epidemiological data from Europe, Australia, and the United States, the IOM report stands as reassurance to parents concerned about the risk of previous vaccinations for their children [14].

Although the AAP and the combined Public Health Service agencies (CDC, NIH and FDA) have taken a precautionary approach in encouraging vaccination of infants with Thimerosalfree products when available (particularly for the most susceptible infants-those that are very premature and undernourished), the ACMT wishes to emphasize that these are also those infants most at risk of vaccine-preventable diseases. The restriction of vaccine access is inappropriate and results in real, as opposed to theoretical, harm $[15,16]$.

The ACMT further discourages chelation therapy in autistic children, a practice that is not supported by clinical evidence either of mercury toxicity or therapeutic effect, which can have hazardous consequences [7].

Lastly, the ACMT commends the IOM report's conclusions encouraging research funding to investigate adverse vaccine concerns, evaluating autistic disorders up through a pre-school catchment age, and related epidemiologic surveillance.

\section{REFERENCES}

1. Immunization Safety Review Committee: Vaccines and Autism. Institute of Medicine. National Academies Press, 2004. www.iom.edu/report.asp?id=20155 www.nap.edu/ catalog;10997.html

2. Brent J. Toxicologists and the Assessment of Risk: The Problem with Mercury. J Toxicol/Clin Toxicol 2001;30: 707-710.

3. Thimerosal in Vaccines (Mercury in Plasma-Derived Products). Center for Biologics Evaluation and Research, FDA. fda.gov/cber/vaccine/thimerosal.htm

4. Madsen KM, Hviid A, Vertergaard M, Schendel D, Wohlfahrt J, Thorsen P, Olsen J, Melbye M. A Population-Based Study of Measles, Mumps and Rubella Vaccination and Autism. N Engl J Med 2002;19:1477-1482.

5. Morris SAS, Bernstein HH. Immunizations, Neonatal Jaundice and Animal-Induced Injuries. Current Opinion in Pediatrics 2004; 16:450-460.
6. Newschaffer CJ, Falb MD, Gurney JG. National Autism Prevalence Trends from US Special Education. Pediatrics

2005; 115 :277-282.

7. Parker SK, Schwartz B, Todd J, Pickering LK. ThimerosalContaining Vaccines and Autistic Spectrum Disorder: A Critical Review of Published Original Data. Pediatrics

2004; 114:793-804.

8. Ruther M. Incidence of Autism Spectrum Disorders: Changes Over Time and Their Meaning. Acta Paediatrica 2005;94:2-15.

9. Chez NG, Chin K. Hung PC. Immunizations, Immunology and Autism (Review). Seminars Ped Neurol 2004; $11: 214-217$.

10. Burbacher TM, Shen DD, Liberato N, Grant KS, Cernichiari E, Clarkson T. Comparison of Blood and Brain Mercury Levels in Infant Monkeys Exposed to Methylmercury or Vaccines Containing Thimerosal. Environmental Health Perspectives 2005;112:1015-1021.

11. Parran DK, Barker A, Ehrich M. Effects of Thimerosal on NGF Signal Transduction and Cell Death in Neuroblastoma Cells. Toxicol Sci 2005;86:132-140.

12. Verstraeten T, Davis RL, DeStefano F, Lieu TA, Rhodes PH, Black SB, Shinefield H, Chen RT. Safety of ThimerosalContaining Vaccines: A Two-Phased Study of Computerized Health Maintenance Databases. Pediatrics 2003;112:1039-1048. www.pediatrics.aappublications.org/cgi/content/full/112/5/ 1039?ijkey=ed4b4475a8522

13. Stehr-Green P, Tull P, Stellfeld M, Mortenson PB, Simpson D. Autism and thimerosal-containing vaccines: lack of consistent evidence for an association. American Journal of Preventive Medicine. 2003;25(2):101-6.

14. Verstraeten T. Thimerosal, the Centers for Disease Control and Prevention, and GlaxoSmith Kline. Pediatrics 2004;113:932 (letter). www.pediatrics.aappublications.org/cgi/content/ full113/4/932

15. Bigham M, Copes R. Thiomersal in vaccines: balancing the risk of adverse effects with the risk of vaccine-preventable disease. Drug Safety. 2005;28(2):89-101, 2005.

16. Elliott VS. Anti-thimerosal laws vex flu shot planners. American Medical News. 2004;49(16):1,4.

17. Boy with Autism Dies after Chelation Therapy: 5-Year-Old Was Receiving Controversial Treatment in Doctor's Office. Associated Press. MSNBC, August 25, 2005. www.msnbc.msa.com/id/9074208 